\title{
An experimental study for environmental fundraising in Majorca, Spain
}

\author{
Maria Claudia Lopez ${ }^{*}, \quad$ Esther Blanco ${ }^{\dagger, *}$
}

Eric A. Coleman ${ }^{\dagger, \S, * *}$

\begin{abstract}
This paper tests the effectiveness of different institutions to fundraise for environmental projects at tourist destinations. We conduct a series of experiments with tourists visiting the Island of Majorca, Spain, and test the fundraising capacity of a voluntary donation scheme, two tax levels, and a matching instrument. Majorca is a major international tourism destination, but tourism activities continue to stress the natural environment making the destination less attractive. This is a common phenomenon in mature tourism destinations. In response, many destinations invest in projects to prevent environmental degradation or for environmental remediation. These projects are traditionally financed by means of public investment, with a consequent tax burden to residents. The most common alternative to fund environmental projects is shifting the tax burden to tourists through tourist-targeted taxation schemes. More recently, programs to gather voluntary donations from tourists have been implemented. In one treatment of our experiment, tourists are given the opportunity to make a voluntary donation to the local environmental organization involved in such projects. In high tax and low tax treatment, tourists are taxed some proportion of their initial endowment and then decide on their level of voluntary contributions from their remaining endowment. In a final treatment, the experimenters match, one-for-one, any voluntary donations. We test the crowding-out hypothesis of taxes over voluntary environmental donations and find imperfect crowding-out (from 60 to 65 percent for different tax levels). Finally, we explore potential crowding-in of matching instruments (widely used in non-tourism settings for fundraising campaigns), but do not find any support for the capacity of matching contributions to increase the level of donations. Because of imperfect crowding-out it may be reasonable to use voluntary donation programs and tourism taxes complementarily (instead of independently, as has been done in Majorca), to increase fundraising for environmental purposes.
\end{abstract}

Keywords: Environmental Fundraising, Tourism, Experiment, Crowding

\footnotetext{
* Pontificia Universidad Javeriana, School of Environmental and Rural Studies

${ }^{\dagger}$ Indiana University, Workshop in Political Theory and policy Analysis

* University of Innsbruck, Institute of Public Finance

$\S$ Florida State University, Department of Political Science.

** Corresponding author. Address: 543 Bellamy, P.O. Box 3062230, Tallahassee, FL 32306-2230. Telephone: 850644-4540. Email: ecoleman@,fsu.edu
} 


\section{Introduction}

Environmental fundraising is a growing policy topic worldwide. Public agencies have taken a lead in implementing policies to avoid or remediate environmental damages. However, policy responses to environmental problems are most often costly. Research, technological improvement, infrastructural change, and remediation of damages, among others, require significant investments. Several instruments have been used to finance these investments, one of which is citizen-targeted fundraising campaigns.

In many tourism destinations, environmental investment is crucial for the long-run survival of the destination. Tourism destinations all over the world are implementing policies to gather funds from tourists visiting the area to develop environmental projects. These projects are aimed to mitigate the negative environmental impacts resulting from the tourism activity. Some examples of these impacts are overuse of fresh water sources, increased air and water pollution, littering, territorial fragmentation, or stress of wildlife (EEA, 2007). Policymakers frequently tax tourists to raise revenue to remediate their environmental damage. Some examples of such environmental taxes are the entry taxes to Belize, exit taxes in Fernando de Noronha, Brazil, or the accommodation tax that was implemented and then abolished in the Balearic Islands, Spain.

Taxes in tourism (not only environmental taxes) are very appealing for public agencies, since they shift a portion of the local tax burden from residents to tourists (who are not voters in the region), without imposing a substantial negative burden on the local tourism industry (Bonham and Gangnes, 1996). Other fundraising mechanisms such as voluntary donations (e.g. Turner et al., 2001) and matching schemes from public agencies are much less popular, more recent, and less studied in the tourism literature. 
In this paper we test to what extent tourists respond to different fundraising mechanisms for environmental purposes in the Island of Majorca, which belongs to the archipelago of the Balearic Islands, Spain. With almost 9 million tourists in 2009, this Island serves more than $1 \%$ of the tourism market worldwide (UNWTO, 2010; INESTUR, 2010). In addition, this case constitutes a particular case where both taxes and voluntary contributions to environmental public goods have been used alternatively in the past. These fundraising strategies had limited success both in terms of their ability to generate revenue (for voluntary contributions currently in place) and engender consistent political support (for environmental taxes that were abolished after two years of operation).

Previous experimental literature has addressed voluntary contributions to public goods (Andreoni, 1993; Cadsby et al., 2007; Chan et al., 2002; Croson and Marks 1998, 2000, 2001; List and Lucking-Reiley, 2002; Jones and McKee, 2009; Marks et al., 1999; Marks and Croson, 1999; Rondeau et al., 1999; Rose et al., 2000; Walker et al, 2000). However, to the best of our knowledge there is no previous experimental study on different instruments for environmental fundraising in tourism destinations. Different methods to fundraise projects by public administrations have been analyzed in the past from an experimental perspective. Some well accepted findings of this literature are: that the zero-contribution hypothesis is not validated (see Zelmer, 2003, for a meta-analysis of linear public goods), taxes can (at least partially) crowd-out voluntary donations (Andreoni, 1993; Chan et al., 2002), and public contributions complementing private donations (e.g. matching instruments or seed money) can increase the size or the number of donations (List and Lucking-Reiley, 2002).

There is an extensive literature from experimental settings showing that people contribute to public goods, even though the traditional model of homo economicus predicts that agents will 
not contribute (Ledyard 1995, Fehr and Schmidt 1999, Zelmer 2003). Studies suggest that these contributions are sensitive to the marginal per capita return of public good investment (Isaac, Walker, and Thomas, 1984 and Isaac and Walker 1988). However, it has also been shown that subjects contribute to public goods, such as charities, even if the per capita return to investment is unknown and in any case very small due to a large group size of people benefiting from the public good.

Andreoni (1993) conducted a laboratory experiment to test the public goods crowdingout hypothesis, obtaining evidence of an imperfect crowding-out effect. He argued that complete crowding-out would entail that average contributions after an imposed tax should be the same as contributions previous to the tax. His design was meant to present the most favorable circumstances for complete crowding-out, but Andreoni's results showed highest total contributions (voluntary and taxed contributions) from taxed groups. Chan et al (2002) conducted a similar laboratory experiment to Andreoni (1993), but with two tax levels. They analyzed the data considering a boundary effect resulting from censoring the range of possible values of voluntary donations as well as considering the possibility of a warm-glow effect. They found that much of the crowding-out is explained by the censoring and that data were consistent with a warm-glow effect.

Another type of related institution is the public-private interaction for funding public goods. List and Lucking-Reiley (2002) conduct a natural experiment on funding computers for an environmental agency of the University of Central Florida. The authors analyze the effect of co-funding (seed money) on the voluntary donations by citizens. Their results show that cofunding increases the participation rate as well as the amount donated. The authors conclude that "field experiments are a promising methodology for other aspects of charitable giving, such as 
matching grant policies and rebate policies for excess contributions" (List and Lucking-Reiley, 2002, p. 231). This experimental study contributes in this direction by testing the effects of different fundraising mechanisms on the relevant subject pool that would be targeted in a touristbased environmental fundraising campaign.

Previous experimental studies with tourists address different research questions to the one analyzed in this study. Alpízar et al (2008a) conduct a natural experiment with international visitors to a Costa Rican National Park. They test for the effect of anonymity, reciprocity and reference contributions on donations to the park. In this same setting, Alípzar et al (2008b) analyze whether respondent donations to the national park are more sensitive to anonymity and reference contributions when making a hypothetical choice compared to a choice that involves an actual payment to the park. They found evidence of a large hypothetical bias, thus stressing the relevance of using actual payments in research with tourists as subject pools than eliciting state preferences willingness to pay. Therefore, we use a framed field experiment ${ }^{1}$ methodology instead of stated preferences to improve the reliability of our findings.

In this paper we assess three mechanisms commonly found in the fundraising literature and relevant for the tourism setting: voluntary donations to a linear public goods, taxes, and matching instruments. We test the effects of having a tax to check whether or not this tax will crowd-out donations. We also explore the fundraising capacity of the matching instrument, very often used for fundraising non-tourism settings, mainly in the US (Karlan and List, 2007; Baker et al 2009). Consistent with previous studies, subjects in our dataset donate positive amounts of money to the linear public good (surprisingly high levels). Further, our results show that tourists participating in the high tax treatment donate the most; this finding does not support a complete

\footnotetext{
${ }^{1}$ According to the taxonomy of Harrison and List (2004), our experiment is a framed field experiment. Our subject pool was drawn from tourists while vacationing in the Island of Majorca.
} 
crowding-out hypothesis. The imperfect crowding-out may be attributed to the fact that individuals behave differently while on vacations than during their daily life, as widely documented by previous sociological and anthropological literature (e.g. Ryan and Kinder, 1996). In addition, we find there is no significant crowding-in by the matching treatment; the matching instrument does not increase the level of voluntary donations by tourists.

This paper is organized as follows; in section 2 we briefly review tourism impacts on the environment, and the different environmental fundraising strategies employed on the island of Majorca. In section 3 we describe the experimental design, and then present our results in section 4. Finally, section 5 concludes.

\section{Background}

Tourism has become one of the major trade categories worldwide. It generates 700 billion euros of receipts, accounting for $30 \%$ of the world's exports of commercial services, and an estimated 5\% of worldwide gross domestic product (UNWTO, 2009a). Its contribution to employment is even higher, estimated in the order of $6-7 \%$ of the overall number of jobs (direct and indirect) (UNWTO, 2009a). For the Balearic Islands the tourism activity constitutes the main economic sector (up to $72 \%$ of value added) and labor generator (68.01\% of employment) (Polo and Valle, 2008). The major pull factors of Majorca (and other destinations worldwide) are ecological attractions (beaches, rainforest, biodiversity, etc.) and scenery systems (beautiful views, impressive landscapes, etc.). This is referred as nature-based tourism, and has been one of the fastest growing segments of the global tourism market for years (Huybers and Bennett 2003; Sirakaya 1997). Nature-based destinations tend to be located in fragile natural environments that rapidly degrade upon un-responsible environmental management (UNWTO 2004). Thus, 
environmental policies to reduce or mitigate impacts are particularly relevant in nature-based destinations. The question that remains is how to fund these environmental policies.

This paper takes as a case the Island of Majorca. The Island served almost 9 million tourists in 2009 (INESTUR, 2010) over a population of 862,397 inhabitants according with latest population $\operatorname{data}^{2}$ (a ratio of more than 10:1). As a result of this strong tourism development over more than 30 years, the destination faces substantial environmental damages resulting from tourism development (Essex et al., 2004; García and Servera, 2003; Gómez et al., 2005; Kent et al., 2002). These accumulative impacts have negatively affected the appeal of the destination and the public opinion regarding tourism. As a reaction, policymakers developed a series of public programs, funded by local taxpayers, to mitigate the environmental impacts generated by tourists. Since the tax burden fell to local taxpayers, such a response was politically unpopular. Two different campaigns to obtain funding from tourists to mitigate their environmental impacts were then applied: an accommodation tax and a voluntary donation program.

Majorca constitutes an extreme case illustrating the vivid socio-political debate in tourism management regarding fundraising of environmental policies. The first policy was a tax on overnight stays and the receipts were ear-marked for environmental purposes, the so-called Balearic Ecotax. This policy was in place for 2 years (2002 and 2003), and raised a total amount of almost 72 million euros ${ }^{3}$. Despite the success in fundraising the policy generated a huge social conflict between the tourism industry, residents, tourists and public administrators. The conflict

\footnotetext{
${ }^{2}$ Data from the National Institute of Statistics of Spain for $1^{\text {st }}$ January 2009 http: $/ /$ www.ine.es/jaxi/menu.do?type=pcaxis\&path= $\% 2 \mathrm{Ft} 20 \% 2 \mathrm{Fe} 260 \% 2 \mathrm{Fa} 2009 \% 2 \mathrm{~F} \&$ file $=$ pcaxis $\& \mathrm{~N}=\& \mathrm{~L}=0$.

${ }^{3}$ Data from personal communication with the tax department of the Government of the Balearic Islands.
} 
escalated to the point that a new party took control of the local government on the platform of abolishing the ecotax. ${ }^{4}$

A policy based on voluntary donations to an environmental fund replaced the old tax system in 2004 , collecting 185,000 euros in $2007 . .^{5}$ This voluntary scheme consists of a so-called Green Card that tourists and residents can buy in different places around the Island (hotels, tourism information points, car rentals, natural protected areas, etc.). It costs 10 euros and includes a combination of public and private goods: investment in environmental projects in the Island jointly with discounts in some tourism attractions and services such as museums, bike rental, and others. This system is currently in place, and is operated by the Foundation for a Sustainable Development of the Balearics Islands (FSB for short), which is a public-private nonprofit organization whose aim is to propel a strategy of sustainable development.

(Representatives from both local government and businesses comprise the governing body of the FSB).

\section{Experimental Design}

We conducted a series of experiments at the end of the summer of 2009 (end of the high tourism season) in the Island of Majorca. The experiments were conducted by three researchers fluent in English (two of them co-authors of this paper), in the departure gates of Palma de Majorca Airport with a total of 118 English speaking participants. ${ }^{6}$ We conducted the

\footnotetext{
${ }^{4}$ Social conflict also arose from hotel room taxes in the Dominican Republic, Puerto Rico, Mexico, and other countries (Gago et al., 2009). According to Gago et al., (2009) conflicts arise because tourists and tourism-based businesses perceive the taxes as discriminatory and provide incentives for bad business practices.

${ }^{5}$ This is the only year for which the FSB has presented their accounting balance, and therefore the only official accounting information available to the moment where this paper was finished.

${ }^{6}$ We had 120 participants, but two participants did not fill completely the forms requested, therefore they were withdrawn from the analysis. The research was restricted to English speaking participants for a combination of reasons. First, British tourists have traditionally been a key tourism market for Majorca, currently constituting the
} 
experiments at the gates of the airport for two reasons. First, it is a common practice in tourism research, mainly for surveys and questionnaires, to approach tourists in airport gates. Because the opportunity cost of tourists' time while at the airport gates is much lower than during the rest of their vacation. Consequently, response rates tend to be reasonable. Second, we explored the possibility of conducting the experiments in other more relaxed locations for tourists, such as hotel halls, in swimming pools, or at the beach, but response rates were extremely low.

For the recruitment process, each one of the participants was approached by one of the three researchers after being seated in their departure gate. The researcher, wearing a t-shirt from the University of the Balearics Islands, in addition to a formal identification with a picture provided and signed by the airport authorities, asked him/her if he/she was willing to participate in an environmental research project. We explicitly mentioned that their contact information was not requested in the study, as this appeared to be a major concern before accepting to participate. $^{7}$ Afterwards, we briefly described the activity as a single decision making experiment that will not last more than 10 minutes, and where the participant could have the opportunity to earn some money.

After agreeing to participate, each subject was handed a folder with three pieces of paper. The first sheet of paper explained that the research was a joint effort of researchers from the University of the Balearic Islands (Spain), Florida State University (US), and Pontificia Universidad Javeriana (Colombia), that participation was voluntary, and that all information was to be treated confidentially. Additionally, a description of the mission and main objectives of the

second major market (almost $22 \%$ of all tourists) after Germans. Second, given budget restrictions choosing English enabled us to include more participants, and avoid translation and other related costs.

${ }^{7}$ The design of the experiment and the survey were carefully constructed in such a way that we did not ask for any information that will give us the possibility to have future contact with the participants. This was done to ensure the transparency of the purpose of the research. 
FSB was provided. Then, an explanation of the decision task, followed by an example was given. In the second piece of paper, participants were asked to privately make their decision. The third sheet presented a questionnaire with socio-economic information and information regarding their experience as a tourist on the island. We answered any questions they had about how to fill the questionnaires when required. Since participation was absolutely voluntary, subjects were free to decline participation at any point.

Subjects were assigned randomly to one of the four possible treatments. In the first treatment, the baseline treatment, subjects were presented with a linear public good game. ${ }^{8} \mathrm{We}$ gave the participant 15 euros, ${ }^{9}$ and asked him/her to allocate up to 15 euros to the FSB. We explained that his/her earnings would consist of the money he/she decided to keep (the portion of the 15 euros he/she was not allocating to the FSB). This treatment served as a control group, i.e. a set of participants with which we could compare the effects of all the other treatments.

The second treatment is the low tax treatment. As in the baseline treatment, each participant started with 15 euros, but in this case he/she was told that 5 euros of this 15 euros were given compulsory the FSB. Then, his/her task was to allocate the remaining 10 euros. His/her earnings will be the money he/she decided to keep from these 10 euros. The third treatment, the high tax, was similar to the previous one, but in this case 10 euros out the initial 15 euros were compulsory allocated to the FSB. His/her decision was to decide whether and how

\footnotetext{
${ }^{8}$ The problem is a linear public goods game in the sense that each euro donated to the FSB is added and given to the FSB which has some value to the subject. It is not a traditional linear public goods game, however, because there is no explicit MPCR imposed by the researchers. Two problems prevented us from implementing a traditional linear public goods game with an identified MPCR. First, the number of people benefiting from the linear public good is unclear to us, and potentially includes any tourist or resident of the Island, who may also contribute in different ways to the conservation of the natural resources of Majorca. Second, the value that any participant happens to place on the public good is uncertain and is impossible to induce by the very nature of the environmental projects. Thus, giving an explicit MPCR or manipulating the MPCR is impossible in this experiment.

${ }^{9}$ At the time of the experiment 1 euro was equivalent to US $\$ 1.47$.
} 
much to voluntarily donate from the reaming 5 euros. Both the low tax and the high tax treatments were aimed to investigate the crowding out hypothesis.

In the last treatment, the matching treatment, the participant started with 15 euros. In this case the participant was told that for each euro he/she allocated to the FSB, we would match the contribution by allocating an additional euro. This last treatment was aimed to explore the effects of the matching instrument in a tourism setting.

For all treatments, the money donated to the FSB was placed in a sealed envelope with the participant number in front of each participant and handled at the end of all sections to the FSB. At the end of the experiment, we told each participant that they could contact the FSB to check that their donation was received. ${ }^{10}$ To facilitate them this process, we gave each participant the first sheet of paper containing the information about the FSB, their e-mail and telephones. Additionally, we wrote their participant number as a mean to track their donation.

Each of the participant's potential earnings varied depending on the treatment of participation: from a maximum of 15 euros in the baseline and matching treatments, to 10 and 5 euros respectively in the low and high tax. Average earnings across treatments was 3.09 euros, with maximum earnings of 15 euros (implying no contributions to the FSB in the baseline and matching treatments) and a minimum of 0 euros (implying full contributions to the FSB).

\section{Results}

Table 1 shows a description of the data used in this analysis. The top variable is the total contribution to the FSB, which consists of the taxed amount in the tax treatments and the matched contributions in the matching treatment in addition to any voluntary contributions. The voluntary contribution is the amount that is voluntarily given to the FSB in the different

\footnotetext{
${ }^{10}$ According to the FSB, no participant contacted them to verify that a donation was made under their participant number.
} 
treatments. In the high tax treatment, for example, the maximum voluntary contribution is 5 euros, while in the low tax treatment the maximum is 10 euros, and in the baseline and matching treatment the maximum voluntary contribution is 15 euros. The remaining variables in Table 1 are control variables and are taken from the survey found in Appendix B.

\section{[TABLE 1 ABOUT HERE]}

We first assess differences in each variable by the four treatment conditions: baseline, high tax, low tax, and matching. Table 2 reports summary statistics for each variable by treatment, as well as the overall summary statistics. This table shows that both total contributions as well as voluntary contributions differ substantially by treatment condition. The p-value in the right-most column is from ANOVA comparisons of an equivalent mean giving across all treatments. The p-value for voluntary contributions is less than 0.001 suggesting that we reject the hypothesis of equivalent voluntary giving across treatments.

\section{[TABLE 2 ABOUT HERE]}

If taxes crowd-out voluntary contributions, then we would expect subjects to give, on average, an equivalent amount regardless of treatment. That is, with perfect crowding-out since subjects are willing to give about 10.5 euros in the baseline condition, we would expect that a lump sum tax of 5 euros would result in average voluntary contributions of about 5.5 euros. In fact, when subjects face the low tax of 5 euros they voluntarily donate about 7.5 euros rather than 5.5 euros predicted by perfect crowding-out. If there were no crowding-out, on the other hand, we would expect subjects to continue to give 10.5 euros on average. However, this value is out of their possible range of donation. Therefore we would expect their donations to be the closest possible value to 10.5 , which is 10 euros, but they only give 7.5 euros. Thus, there is imperfect crowding-out. In the literature the percentage of crowding is measured as the change in voluntary 
contributions divided by the change in the tax rate (see Chan et al., 2002). For the low tax treatment we measure $(7.5-10.533) / 5=60.7$ percent crowding-out and in the high tax treatment we measure (4.036-10.533)/10 $=65$ percent crowding-out. Thus, crowding-out is increasing in the tax rate, as expected, although this difference is not statistically significant. ${ }^{11}$

Analyzing the crowding-in from the matching treatment is more difficult. If there is crowding-in from the matching treatment then we would expect higher voluntary contributions in this treatment than compared to the baseline. Table 2 shows a slightly higher proportion of voluntary contributions in the matching treatment, but this difference is substantively small and not statistically significant (see next section).

Figure 1 shows the total contributions, in euros, across all four treatments. In the baseline condition, subject gave just over 10.5 euros from the 15 possible euros of endowment. In the low tax treatment subjects gave 7.5 of from the 10 euros they were asked to distribute and in the high tax treatment subjects gave just over 4 euros from the 5 euros they could allocate. In the matching contribution, subjects gave about 10.7 euros that were then matched by the experimenter. Thus, the total (voluntary, mandatory, and matched) contributions to the FSB were greatest in the matching treatment, followed by the high tax treatment, low tax treatment, and then the baseline.

\section{[FIGURE 1 ABOUT HERE]}

Also noteworthy from Table 2 is the high number of previous stays in the destination by subjects in our sample. This reflects the large number of repeat visitors in the Balearic Islands, where $54 \%$ of total international arrivals are attributable to habit persistence and/or word-of-

\footnotetext{
${ }^{11}$ A test of equivalence crowding-out in the two tax treatments was performed after the regressions presented in the next section. In Table 4, model 1, we performed a Wald-test of equivalent coefficients for high tax lump sum and low tax lump sum; we fail to reject equivalent crowding-out, $F(1,114)=0.06, p=0.815$.
} 
mouth effects (Garín-Muñoz and Mortero-Martín, 2007). The remaining control variables, except age, are relatively similar across treatments. There is a significant difference in age across treatment conditions with older tourists more likely to have participated in the low tax and baseline conditions and younger subjects more likely to have participated in the matching and high tax conditions. While subjects were randomly assigned to treatment they do differ statistically on this measure. $^{12}$

To estimate the effects of each treatment on voluntary contributions we ran a series of regressions reported in Table 3. For each treatment two separate models were estimated. The first model estimates voluntary donations as a function of the treatment conditions, while the second model includes the set of control variables reported in Table 1.

\section{[TABLE 3 ABOUT HERE]}

In order to get a direct measure of crowding-out in the regression analysis, the overall amount of the tax must be accounted for in each treatment. Thus, for the high tax and low tax treatments (columns 1-4) we include as the treatment variable the lump sum taxes for the respective treatment (i.e. $=5$ in the low tax treatment, $=10$ in high tax treatment) interacted with a dummy variable indicating the treatment condition. We refer to this measure as the lump sum high tax in the high tax treatment and the lump sum low tax in the low tax treatment. Coding the variable in this format allows direct estimation of the percentage of crowding-out (see Chan et al., 2002). If $y$ is the dependent variable measuring voluntary contributions and $x$ is the lump sum tax rate, with relationship $y=x \beta+a$, then $=\frac{d y}{d x}$ is a direct measure of crowding-outthe marginal change in voluntary donations given a marginal change in the tax rate for the

\footnotetext{
${ }^{12}$ This does not suggest that the randomization process was flawed, but may simply reflect that those in the treatment group may, by chance, be different in some way than those in the control group. Because age is the only variable for which randomization is not independent we conjecture that the dependence rose not due to flaws in randomization but due to chance.
} 
respective treatment (rather than a discrete change if we were to use only dummy variables indicating treatment condition). Table 3 shows that crowding-out is measured in the high tax treatment as -0.65 and is measured in the low tax treatment as -0.61 (both significant at the 0.01 level). Thus, we reject the hypothesis of no crowding-out. However, because both values are greater than -1 there is imperfect crowding-out. ${ }^{13}$

The estimated treatment effects of the high and low tax treatments remain significant and of a similar magnitude when control variables are included. Trip experience is negatively correlated to voluntary contributions, although only weakly significant at the 0.10 level. Environmentalism is a significant predictor of giving in the high tax treatment and although not statistically significant, is substantively large in the low tax treatment. Being from a country that utilizes the euro is also a significant predictor of behavior, although these measures are based off only two subjects in the high tax treatment and only one subject in the low tax treatment. As anticipated, subjects that could directly use euros when arriving in their home country gave fewer euros to the FSB before departure (significant at the 0.05 level in both treatments). The remaining control variables are not statistically significant.

The results from the matching treatment are more ambiguous. As might be expected from the small difference in mean voluntary donations reported in Table 2, there is not a significant difference in voluntary donations between those in the matching treatment and those in the baseline treatment. For regressions (5) and (6) in Table 3 we code the matching treatment as a dummy variable. The estimated coefficients, therefore, represent mean differences in voluntary contributions from the baseline. These are not statistically significant nor are any of the control

\footnotetext{
${ }^{13} \mathrm{~F}$-tests were performed to test the hypothesis that the coefficient is equal to -1 for each treatment. For the high tax treatment, $\mathrm{F}(1,56)=11.22, \mathrm{p}=0.002$, and for the low tax treatment, $\mathrm{F}(1,58)=3.27, \mathrm{p}=0.076$. This provides evidence of imperfect crowding.
} 
variables used in the matching treatments. Because the matching conditions do not appear to increase voluntary donations, we reject the crowding-in hypothesis for the matching treatment.

Table 4 shows the estimated coefficients when pooling the data from all treatments. Columns (1) and (2) present the ordinary least squares (OLS) estimates, while columns (3) and (4) report estimates from a robust regression following Chan et al. (2002) to mitigate the effects of outliers. Results from the robust regressions are broadly consistent with the OLS, except that the estimated treatment effects tend to be of larger magnitude, implying more crowding-out than measured with OLS.

\section{[TABLE 4 ABOUT HERE]}

\section{Discussion of Results}

It is clear from the previous section that taxation does crowd-out environmental donations among tourists in Majorca, but that the crowding-out is imperfect. When the lump sum tax of 5 euros was imposed on a 15 euros endowment, giving to the FSB was crowded-out by about 60 percent. When the lump sum rose to 10 percent, giving to the FSB was crowded-out by about 65 percent. This implies that tourists are affected by a tax, but that they may continue to give voluntary donations in the face of a tax. ${ }^{14}$

\footnotetext{
${ }^{14}$ Yet there may be two potential ways in which the Majorca ecotax affected other sources of environmental fundraising present on the Island: the direct crowding-out of voluntary donations to support the environment or a decrease in tourism visits. Studies forecasting the effect of the Majorca ecotax estimated a reduction of 117,660 tourists due to the tax, i.e. a 1.44\% decrease in number of tourists of the year 2000 (Aguiló et al 2005). However, a later study using panel data until 2003 to analyze tourism demand to the Balearic Islands, did not find a significant effect of the ecotax on the number of arrivals (Garín-Muñoz and Montero-Martín, 2007). Other studies analyzing the impact of the 5\% Hawaii hotel room tax (which generated in $\$ 82$ million of revenue in 1990, making it the third largest source of state revenue) did not find a statistically significant impact on visitors (Bonham and Gangnes, 1996). Thus, if the number of tourists is not greatly influenced by the ecotax and the amount that can be raised per tourist is not completely crowded-out by the ecotax, then such a policy may prove a valid way to raise funds for environmental protection and remediation.
} 
Figure 1 shows that the greatest total donations to the FSB occurred with matching contributions. If the goal is to raise revenue for the environmental group then such a policy may seem attractive. However, governments still must find and implement matching funds to achieve this level of environmental investment (half of the raised revenue would come from such sources). The matching treatment did not crowd-in additional funds for the FSB; thus, such a mechanism may not be an efficient way to induce tourists to voluntarily donate.

The results instead suggest that governments that impose high taxes do not completely crowd-out environmental donations in tourism settings. This can increase revenues to environmental organizations through such taxes, relative to a baseline scenario where there are no taxes. Of course generalizing these results to larger endowments is problematic. However, at least at low levels of environmental donations tourists do not seem to give any fewer voluntary contributions to environmental groups than when taxes are imposed. An instrument to shift the tax burden away from local users (i.e. matching) and onto tourists (i.e. taxation) may also be more palatable politically (Jensen and Wanhill, 2002).

Previous studies have analyzed the economic implications of taxes in the tourism industry, showing that taxes are mostly assumed by tourists (and not the tourism industry) (Jensen and Wanhill, 2002). For the specific case of the Balearic Islands, estimates point to a price elasticity between $-0.76 \%$ and $-1 \%$ for the short run and of $-1.65 \%$ for the long run (Aguiló et al. 2005; Garin-Muñoz and Montero Martin, 2007). According with Garin-Muñoz and Montero Martin (2007) the short run price elasticity could lead to thinking that revenues can be increased by increasing prices (e.g. imposing a tax), but the long run price elasticity reflects the numerous substitute destinations available for consumers. For other origin regions and destinations the short and long run price-elasticity substantially varies, between -0.10 and -1.06 , 
and -0.044 and -2.16 respectively (Garín-Muñoz, 2007). Thus, extrapolation of findings of this study should be also restricted to destinations where the price-elasticity of origin markets is comparable to the estimates for the Balearic Islands.

There are a number of limitations to our results. First, our estimates of crowding-out are affected by the boundary conditions of the experimental design. Many subject decisions took place on the boundary space of the experiment. In this experimental design there is no interior solution; income-maximizing subjects would either give nothing if they perceive the marginal per capita return (MPCR) greater than 1 or give nothing if they perceive it to be less than 1 . The fact that many of the subjects gave the full endowment in all treatments suggests that the perceived MPCR of the public good being provided by the FSB is greater than $1 .{ }^{15}$ This also creates a censoring problem in the econometric analysis, where the censoring point shifts depending on treatment (the maximum allowable voluntary donation in the baseline and in the matching treatments is 15 , while in the high tax treatment it is 5 , and in the low tax treatment it is 10). Because of the high voluntary contributions in the baseline treatment, it is not even possible to observe a 0 percent crowding out scenario in either of the tax treatments. Thus, the estimated results should be interpreted as upper bounds on the possible crowding-out. ${ }^{16}$ In other words, environmental taxes might not affect tourists visiting Majorca as much as we measure here.

Another limitation of the study is that tourists coming to Majorca are advised not to interact with people in the streets and be aware of swindlers. We think this may have influenced people's behavior during the experiment even though we were in a safe place such as the gate of

\footnotetext{
${ }^{15}$ If might also be explained if subjects are less self-interested with windfall earnings as opposed to earned money (Cherry et al., 2002)

${ }^{16}$ If subjects are allowed to donate even more in the face of an environmental tax, then there is less potential for crowding-out.
} 
the airport were only authorized people can have access and we were wearing identification cards from the airport and t-shirts from the University of the Balearics Islands. As from the previous comment all our results are influenced by this limitation, but this may be an explanation for the willingness to donate everything to the FSB. Time shortage and stress related to being on the way to take an airplane also seemed to limit the participation and attention that tourists placed on the experiment. However, as stated in section 3, approaching tourists in departure gates is very common in tourism research.

\section{Conclusion}

Traditional fundraising policies for environmental purposes at tourism destinations have relied on public investment, with the consequent tax burden to residents. In mature destinations with high visitations numbers this might represent a direct subsidy from residents to the tourism industry, which benefits from increased tourism appeal of the region. Residents' dissatisfaction with this increased taxing has led public authorities at tourism destinations to look for alternative fundraising mechanisms. The most popular alternative has been the imposition of taxes to tourists, following the polluter pays principle. This policy is alleged to be easier politically, insofar it shifts the tax burden to non-voters to the region. However, in destinations where the tourism industry constitutes a major economic activity, lobbying from the tourism industry might prevent or abolish the imposition of taxes to tourists. As a result, voluntary fundraising mechanisms have recently been implemented. Voluntary and obligatory instruments have been applied most often as independent policies, and weak attention has been devoted to complementarities between the two.

This paper presents a framed field experiment with tourists visiting Majorca, to study the effectiveness of different instruments for environmental fundraising in tourism destinations. Our 
results suggest that taxes imperfectly crowd-out voluntary donations (from 60 to 65 percent crowding-out for different tax levels). This implies that taxes may be used in combination with voluntary instruments for environmental donations in order to enhance fundraising for environmental projects. This, applied for the case of Majorca, may constitute a shift from previous policy orientation.

This paper also explores the potential crowding-in of voluntary donations of a matching instrument, but we do not find any support for crowding-in. Thus, it seems that tourists do not respond a higher capacity to fundraise environmental project of their private donations, only considering their private welfare change.

The results on crowding-out might be conditioned from boundary effects of the experimental design. This implies that our findings should be interpreted as an upper boundary on the possible crowding-out. Further, our data might be also affected by the particular subject pool under analysis: tourists show higher stress levels, higher reluctance to interact with strangers, and the results might be affected from currency exchanges (pound-euro in this case).

Further research could explore potential national differences in the response to fundraising mechanisms in environmental fundraising at tourism destinations. In addition, initial results of this paper support the relevance of fundraising strategies combining a mix of policy instruments, which might show complementarities in its application. Lastly, it might be interesting to explore issues related to the legitimacy of imposition, e.g. will tourists show weaker crowding-out from taxes that they decide to self-impose?

\section{Acknowledgements}

We are particularly grateful to James Walker for all the time he spent advising us and his critical comments on the experimental design. We would also like to support received during data 
collection from Pere Juanico, and several faculty members of the University of the Balearic Islands, especially Francesc Sastre, Eugeni Aguiló and Natividad C. Juaneda. We received valuable suggestions at the $4^{\text {th }}$ Nordic Conference on Behavioral and Experimental Economics, held in Oslo, Noway, in 2009, and from the Experimental Economics Reading Group from Bogotá, Colombia. Financial support from the Government of the Balearic Islands is gratefully acknowledgement. We assume complete responsibility for the final contents of this paper.

\section{References}

Aguiló, E., Riera, A., and Rosselló, J. (2005) The short-term price effect of a tourist tax through a dynamic demand model. The case of the Balearic Islands. Tourism Management, 26, 359-365.

Alpizar, F., Carlsson F., and Johansson-Stenman, O. (2008a). Anonymity, reciprocity, and conformity: Evidence from voluntary contributions to a national park in Costa Rica. Journal of Public Economics 92, 1047-1060.

Alpizar, F, Carlsson F., and Johansson-Stenma, O. (2008b) Does context matter more for hypothetical than actual contributions? Evidence from a natural field experiment. Experimental Economics 11, 299-314.

Andreoni. J. (1993). An experimental test of the public goods crowding-out hypothesis. The American Economic Review, 83(5), 1317-1327.

Baker, R., Walker, J.., and Williams, A. (2009). Matching contributions and the voluntary provision of a pure public good: Experimental evidence. Journal of Economic Behavior and Organization, 70, 122-134.

Bonham, C.S., and Gangnes, B. (1996). Intervention analysis with cointegrated time series: the case of the Hawaii hotel room tax. Applied Economics, 28, 1281-1293. 
Cadsby, C.B., Hamaguchi, Y., Kawagoe, T., Maynes, E., Song, F. (2007). Cross-National Gender Differences in Behavior in a Threshold Public Goods Game: Japan versus Canada. Journal of Economic Psychology, 28 (2), 242-260.

Chan, K.S., Godby, R., Mestelman, S., Muller R.A. (2002) Crowding-out voluntary contributions to public goods. Journal of Economic Behavior \& Organization, 48, 305317.

Cherry, T.L., Frykblom, P., and Shogren, J.F. (2002) Hardnose the Dictator. The American Economic Review 92, 1218-1221.

Croson, R. and Marks, M. (1998). Identifiability of Individual Contributions in a Threshold Public Goods Experiment. Journal of Mathematical Psychology, 42(2-3), 167-190.

Croson, R. and Marks, M (2000). Step returns in threshold public goods: A meta- and experimental analysis. Experimental Economics, 3(2), 239-259.

Croson, R. and Marks, M (2001). The effect of recommended contributions in the voluntary provision of public goods. Economic Inquiry, 39 (2), 238 - 249.

EEA (Editors) (2007). Europe's environment: The fourth assessment. European Environment Agency, Copenhagen.

Essex, S., Kent, M., and Newnham, R. (2004). Tourism Development in Mallorca: Is Water Supply a Constraint? Journal of Sustainable Tourism, 12(1): 4-28.

Fehr, Ernst and Klaus Schmidt. (1999) A theory of fairness, competition and cooperation. Quarterly Journal of Economic, 114(3), 817-68

Gago, A., Labandeira, X., Picos, F., and Rodríguez, M. (2009). Specific and general taxation of tourism activities. Evidence from Spain. Tourism Management, 20,381-392. 
García, C., and Servera, J. (2003). Impacts of Tourism Development on Water Demand and Beach Degradation on the Island of Mallorca (Spain). Geografiska Annaler, 85 A(3-4): 287-300.

Garín-Muñoz, T., and Montero-Martín, L.F. (2007). Tourism in the Balearic Islands: A dynamic model for internacional demand using panel data. Tourism Management, 28, 1224-1235.

Garín-Muñoz, T. (2007). German demand for tourism in Spain. Tourism Management, 28, 1222.

Greene, William H. (2003). Econometric Analysis, $5^{\text {th }}$ Edition. Upper Saddle River, NJ: Prentice Hall.

INESTUR (2010). El turisme a les Illes Balears- Any 2009. Conselleria de Turisme, Govern de les Illes Balears.

Jensen, Thomas C. and Stephen Wanhill. (2002) Tourism's taxing times: value added tax in Europe and Denmark. Tourism Management 23: 67-79.

Jones and McKee 2004. Feedback Information and Contributions to Not-for-Profit Enterprises: Experimental Investigations and Implications for Large-Scale Fund-Raising. Public Finance Review, 32(5), 512-527.

Harrison, Glen W. and John List (2004). Field Experiments. Journal of Economic Literature. 42 (4), 1009-1055

Isaac, M.,Walker, J., and Thomas, S. (1984). Divergent Evidence on Free-riding: An Experimental Examination of Possible Explanations. Public Choice. 43, 113-149.

Isaac,R .M. and Walker,J .M. (1988). G roups ize effectsi n publicg oods provision: The voluntary contributions mechanism. Quarterly Journal of Economics 103, 179-199. 
Karlan, D., List, J. (2007). Does price matter in charitable giving? Evidence from a large-scale natural field experiment. American Economic Review 97,1774-1793.

Kent, M., Newnham, R., and Essex, S. (2002). Tourism and Sustainable Water Supply in Mallorca: A Geographical Analysis. Applied Geography, 22: 351-374.

Ledyard, J. (1995). Public goods: A survey of experimental research. The Handbook of Experimental Economics. In J. Kagel and A. Roth Eds. Princeton, Princeton University Press. 111-194.

Lipford, J. (1995) Group Size and the Free-Rider Hypothesis: An Examination of New Evidence from Churches. Public Choice, 83(3-4) 291-303

List, J. and Lucking-Reiley, D. (2002). The Effects of Seed Money and Refunds on Charitable Giving: Experimental Evidence from a University Capital Campaign. Journal of Political Economy, 110, 215-233.

Marks, M. and Croson, R. (1999). The effect of incomplete information on a threshold public goods experiment. Public Choice, $99,(1-2), 103-118$.

Marks, M.., Schansberg, D.E., and Croson, R. (1999). Using Suggested Contributions in Fundraising for Public Good: An Experimental Investigation of the Provision Point Mechanism. Nonprofit Management and Leadership, 9 (4), 369 - 384.

Polo, C. and Valle, E. (2008). An assessment of the impact of tourism in the Balearic Islands. Tourism Economics, 14, 615-630.

Rondeau, D., D. Schulze, W. and Poe, G. (1999). Voluntary revelation of the demand for public goods using a provision point mechanism. Journal of Public Economics, 72(3), 455-470. 
Rose, S.K., Clark, J., Poe, G. Rondeau, D., Schulze, W.D. (2002). The private provision of public goods: tests of a provision point mechanism for funding green power programs. Resource and Energy Economics, 24, (1-2), 131-155.

Ryan, C., and Kinder, R. (1996). Sex, tourism and sex tourism: fulfilling similar needs? Tourism Management, 17, 507-518.

Turner, R., Miller, G., and Gilbert, D. (2001). The role of UK charities and the tourism industry. Tourism Management, 22, 463-472.

UNEP-UNWTO (Editors) (2005). Making tourism more sustainable. A guide for policy makers. United Nations Environment Programme, Paris.

UNWTO (Editors) (2009). Tourism highlights 2009 edition. United Nations World Tourism Organization, Madrid.

UNWTO (Editors) (2010). UNWTO World Tourism Barometer. Volume 8, No.1, January 2010. United Nations World Tourism Organization, Madrid.

Walker, J, Gardner, R., Herr, A., and Ostrom, E. (2000). Collective Choice in the commons: Experimental results on proposed allocation rules and votes. The Economic Journal, 110(460), 212-234.

Zelmer, J. (2003) Linear public goods experiments: A meta-analysis. Experimental Economics, 6, 299-310. 
Tables

Table 1. Description of Variables

\begin{tabular}{|c|c|c|}
\hline Variable & Description & Type of Variable \\
\hline Total Contribution & The sum of voluntary contribution plus tax & Continuous $(0-15)$ \\
\hline Voluntary Contribution & The voluntary contribution made by subject & Continuous $(0-15)$ \\
\hline Trip Experience ${ }^{a}$ & $\begin{array}{l}\text { An additive index of variables used to assess } \\
\text { the subject's satisfaction with their trip. }\end{array}$ & Ordinal $(0-45)$ \\
\hline Environmentalism $^{b}$ & $\begin{array}{l}\text { An additive index of variables used to assess } \\
\text { the subject's environmental preferences. } \\
\text { The number of visits the subject has made to }\end{array}$ & Ordinal (0-4) \\
\hline Number of Visits & $\begin{array}{l}\text { Majorca. } \\
\text { Age of subject measured on a four-category }\end{array}$ & Ordinal (1-100) \\
\hline $\operatorname{Age}^{c}$ & scale. & Ordinal (1-4) \\
\hline Education $^{d}$ & $\begin{array}{l}\text { Education of subject measured on a six- } \\
\text { category scale. } \\
\text { Home country of subject officially uses the }\end{array}$ & Ordinal (1-6) \\
\hline Eurozone Country & Euros as currency & Binary $(0,1)$ \\
\hline
\end{tabular}

${ }^{a}$ This index is taken from a series of nine questions we asked the subjects about their vacation experience. Subjects were asked to rank, on a scale of 1 to 5 , their satisfaction with the scenery, beach, environmental quality, cleanliness of public areas, prices, treatment as a customer, hospitality from local people, safety and security, and tourist information. A factor analysis confirmed that these measures co-vary closely together on a single underlying factor; for ease of interpretation a single additive index was formed.

${ }^{\mathrm{b}}$ This index is taken from the following four questions we asked the subjects about their environmental preferences: 1) Whether or not one of the top four reasons they came to the island was to enjoy the landscape and nature; 2) Whether they make donations to causes dealing with environmental protection; 3) whether they have a close contact to nature (hiking, biking, etc.) in their home country; 4) Whether they visit protected natural areas in their home country. A factor analysis confirmed that these measures co-vary closely together on a single underlying factor; for ease of interpretation a single additive index was formed.

${ }^{\mathrm{c}}$ The categories are: 1) 30 years or below; 2) Between 31 and 45; 3) Between 46 and 60; 4) 61 or older.

d The categories are: 1) No formal education; 2) Pre-school or kindergarten; 3) Primary school; 4) Secondary school; 5) Bachelor degree; 6) Master's or PhD. 
Table 2. Summary Statistics by Treatment Condition

\begin{tabular}{lcccccc}
\hline & Baseline & High Tax & Low Tax & Matching & All & p-value $^{\mathbf{a}^{\mathbf{2}}}$ \\
\hline Total Contribution & 10.533 & 14.036 & 12.500 & 21.433 & 14.636 & 0.004 \\
& $(5.22)$ & $(1.90)$ & $(2.87)$ & $(10.27)$ & $(7.29)$ & \\
Voluntary Contribution & 10.533 & 4.036 & 7.500 & 10.717 & 8.267 & $<0.001$ \\
& $(5.22)$ & $(1.90)$ & $(2.87)$ & $(5.14)$ & $(4.84)$ & \\
Trip Experience & 33.767 & 34.357 & 35.233 & 34.600 & 34.492 & 0.828 \\
& $(7.23)$ & $(6.66)$ & $(4.98)$ & $(5.30)$ & $(6.05)$ & \\
Environmentalism & 1.600 & 1.250 & 1.367 & 1.133 & 1.339 & 0.367 \\
& $(0.89)$ & $(1.00)$ & $(1.22)$ & $(1.07)$ & $(1.06)$ & \\
Number of Visits & 9.069 & 8.964 & 10.667 & 6.767 & 8.863 & 0.789 \\
& $(12.12)$ & $(11.75)$ & $(22.30)$ & $(9.47)$ & $(14.71)$ & \\
Age & 2.633 & 2.143 & 2.767 & 1.967 & 2.381 & 0.010 \\
& $(0.96)$ & $(1.11)$ & $(1.19)$ & $(0.93)$ & $(1.09)$ & \\
Education & 4.667 & 4.464 & 4.333 & 4.345 & 4.453 & 0.311 \\
& $(0.66)$ & $(0.92)$ & $(0.92)$ & $(0.48)$ & $(0.77)$ & \\
Eurozone Country & 0.207 & 0.071 & 0.033 & 0.200 & 0.128 & 0.103 \\
Observations & $(0.41)$ & $(0.26)$ & $(0.18)$ & $(0.41)$ & $(0.34)$ & \\
\hline
\end{tabular}

Notes: Means with standard deviations in parentheses. ${ }^{\text {a }}$ The p-value is taken from an ANOVA of the indicated variable to test if there is a significant difference in that variable across the four experimental conditions. 
Table 3. OLS Model Estimates of Voluntary Contributions

\begin{tabular}{|c|c|c|c|c|c|c|}
\hline & $\begin{array}{c}(1) \\
\text { High Tax }\end{array}$ & $\begin{array}{c}(2) \\
\text { High Tax }\end{array}$ & $\begin{array}{c}\text { (3) } \\
\text { Low Tax }\end{array}$ & $\begin{array}{c}(4) \\
\text { Low Tax }\end{array}$ & $\begin{array}{c}\text { (5) } \\
\text { Matching }\end{array}$ & $\begin{array}{c}\text { (6) } \\
\text { Matching }\end{array}$ \\
\hline High Tax Lump Sum & $\begin{array}{l}-0.650 * * * \\
(0.10)\end{array}$ & $\begin{array}{l}-0.667 * * * \\
(0.10)\end{array}$ & & & & \\
\hline Low Tax Lump Sum & & & $\begin{array}{l}-0.607 * * * \\
(0.22)\end{array}$ & $\begin{array}{l}-0.753 * * * \\
(0.22)\end{array}$ & & \\
\hline Matching Dummy & & & & & $\begin{array}{r}0.183 \\
(1.34)\end{array}$ & $\begin{array}{c}-0.040 \\
(1.75)\end{array}$ \\
\hline Trip Experience & & $\begin{array}{c}-0.198^{*} \\
(0.10)\end{array}$ & & $\begin{array}{c}-0.221^{*} \\
(0.12)\end{array}$ & & $\begin{array}{l}-0.105 \\
(0.17)\end{array}$ \\
\hline Environmentalism & & $\begin{array}{l}1.568^{* * *} \\
(0.55)\end{array}$ & & $\begin{array}{c}0.686 \\
(0.50)\end{array}$ & & $\begin{array}{c}0.485 \\
(0.76)\end{array}$ \\
\hline Number of Visits & & $\begin{array}{l}0.022 \\
(0.05)\end{array}$ & & $\begin{array}{r}-0.025 \\
(0.03)\end{array}$ & & $\begin{array}{r}-0.077 \\
(0.07)\end{array}$ \\
\hline Age & & $\begin{array}{r}0.001 \\
(0.55)\end{array}$ & & $\begin{array}{r}0.751 \\
(0.61)\end{array}$ & & $\begin{array}{c}0.356 \\
(0.94)\end{array}$ \\
\hline Education & & $\begin{array}{c}0.202 \\
(0.66)\end{array}$ & & $\begin{array}{c}-0.451 \\
(0.70)\end{array}$ & & $\begin{array}{c}-0.958 \\
(1.42)\end{array}$ \\
\hline Eurozone Country & & $\begin{array}{l}-5.028 * * * \\
(1.61)\end{array}$ & & $\begin{array}{c}-4.225^{* *} \\
(1.76)\end{array}$ & & $\begin{array}{r}-1.380 \\
(1.92)\end{array}$ \\
\hline Constant & $\begin{array}{l}10.533^{* * *} \\
(0.73)\end{array}$ & $\begin{array}{l}14.794 * * * \\
(5.20)\end{array}$ & $\begin{array}{l}10.533 * * * \\
(0.77)\end{array}$ & $\begin{array}{l}18.404^{* * *} \\
(6.17)\end{array}$ & $\begin{array}{l}10.533 * * * \\
(0.95)\end{array}$ & $\begin{array}{l}17.990^{*} \\
(9.73)\end{array}$ \\
\hline$R$-Squared & 0.408 & 0.573 & 0.118 & 0.335 & 0.000 & 0.065 \\
\hline Adj. $R$-Squared & 0.398 & 0.510 & 0.103 & 0.242 & -0.017 & -0.068 \\
\hline$F$ & $38.628 * * *$ & $9.188 * * *$ & $7.780 * * *$ & $3.605 * * *$ & 0.019 & 0.488 \\
\hline$N$ & 58 & 56 & 60 & 58 & 60 & 57 \\
\hline
\end{tabular}

Notes: Standard Errors in Parentheses. Two-sided hypothesis tests: ${ }^{*} \mathrm{p}<0.10,{ }^{* *} \mathrm{p}<0.05,{ }^{* * *} \mathrm{p}<0.01$. 
Table 4. OLS and Robust Regression Model Estimates of Voluntary Contributions

\begin{tabular}{|c|c|c|c|c|}
\hline & $\begin{array}{c}(1) \\
\text { OLS } \\
\end{array}$ & $\begin{array}{c}(2) \\
\text { OLS } \\
\end{array}$ & $\begin{array}{c}\text { (3) } \\
\text { Robust } \\
\text { Regression }\end{array}$ & $\begin{array}{c}(4) \\
\text { Robust } \\
\text { Regression }\end{array}$ \\
\hline High Tax Lump Sum & $\begin{array}{l}-0.650 * * * \\
(0.11)\end{array}$ & $\begin{array}{c}-0.609 * * * \\
(0.11)\end{array}$ & $\begin{array}{l}-0.691 * * * \\
(0.11)\end{array}$ & $\begin{array}{c}-0.744 * * * \\
(0.10)\end{array}$ \\
\hline Low Tax Lump Sum & $\begin{array}{l}-0.607 * * * \\
(0.21)\end{array}$ & $\begin{array}{l}-0.644 * * * \\
(0.22)\end{array}$ & $\begin{array}{l}-0.682 * * * \\
(0.22)\end{array}$ & $\begin{array}{l}-0.935^{* * *} \\
(0.20)\end{array}$ \\
\hline Matching Dummy & $\begin{array}{c}0.183 \\
(1.05)\end{array}$ & $\begin{array}{c}0.789 \\
(1.11)\end{array}$ & $\begin{array}{r}0.267 \\
(1.11)\end{array}$ & $\begin{array}{c}0.851 \\
(1.03)\end{array}$ \\
\hline Trip Experience & & $\begin{array}{c}-0.068 \\
(0.07)\end{array}$ & & $\begin{array}{r}-0.087 \\
(0.07)\end{array}$ \\
\hline Environmentalism & & $\begin{array}{c}0.439 \\
(0.36)\end{array}$ & & $\begin{array}{r}0.513 \\
(0.34)\end{array}$ \\
\hline Number of Visits & & $\begin{array}{c}-0.032 \\
(0.03)\end{array}$ & & $\begin{array}{l}-0.041 \\
(0.03)\end{array}$ \\
\hline Age & & $\begin{array}{l}0.972 * * \\
(0.41)\end{array}$ & & $\begin{array}{l}1.308^{* * * *} \\
(0.38)\end{array}$ \\
\hline Education & & $\begin{array}{r}0.012 \\
(0.52)\end{array}$ & & $\begin{array}{c}0.107 \\
(0.48)\end{array}$ \\
\hline Eurozone Country & & $\begin{array}{r}-1.240 \\
(1.16)\end{array}$ & & $\begin{array}{l}-2.995^{* * * *} \\
(1.07)\end{array}$ \\
\hline Constant & $\begin{array}{l}10.533 * * * \\
(0.74)\end{array}$ & $\begin{array}{l}10.156^{* *} \\
(4.05)\end{array}$ & $\begin{array}{l}10.996 * * * \\
(0.79)\end{array}$ & $\begin{array}{l}11.100^{* * *} \\
(3.73)\end{array}$ \\
\hline$R$-Squared & 0.311 & 0.373 & 0.318 & 0.524 \\
\hline Adj. R-Squared & 0.293 & 0.319 & 0.300 & 0.483 \\
\hline$F$ & $17.145^{* * *}$ & $6.945 * * *$ & $17.710 * * *$ & $12.844 * * *$ \\
\hline$N$ & 118 & 115 & 118 & 115 \\
\hline
\end{tabular}

Notes: Standard Errors in Parentheses. Two-sided hypothesis tests: ${ }^{*} \mathrm{p}<0.10,{ }^{* *} \mathrm{p}<0.05,{ }^{* * *}$ $\mathrm{p}<0.01$. 


\section{Figures}

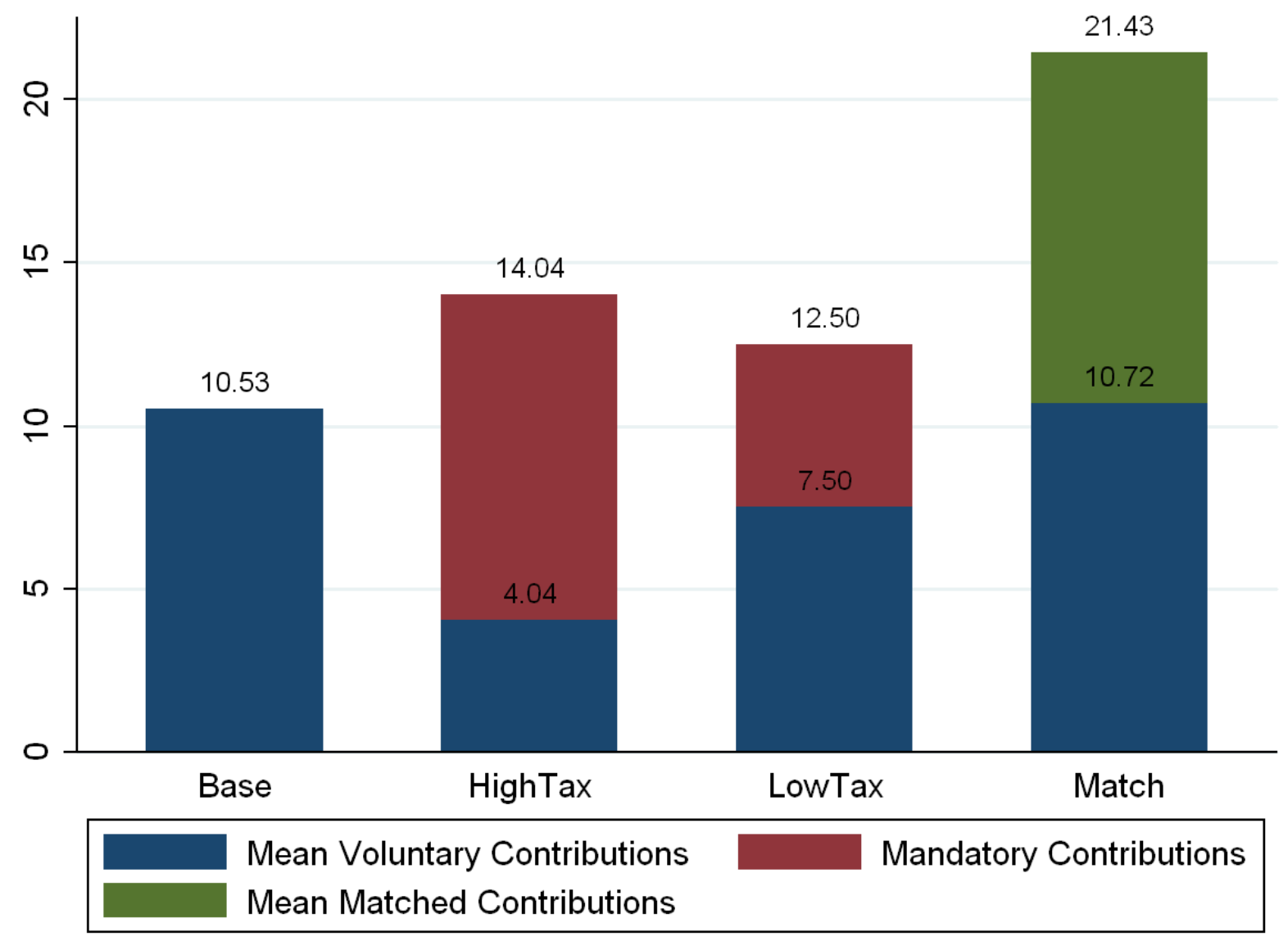

\section{Figure 1. Mean Voluntary, Mandatory, and Matched Contributions by Treatment Condition}

The numbers above the bars indicate the cumulative mean. In the Base condition subjects contributed 10.5 Euros on average; in the High Tax condition subjects voluntary contributed about 4 Euros, on average, and there was also a mandatory contribution of 10 additional Euros for a total contribution of about 14 Euros; in the Low Tax condition subjects voluntary contributed about 7.5 Euros, on average, and there was also a mandatory contribution of 5 additional Euros for a total contribution of about 12.5 Euros; in the Matching condition subjects voluntary contributed about 10.7 Euros, on average, and this was matched by 10.7 additional Euros for a total contribution of about 21.43 Euros. 


\section{Appendix A. Instructions and Decision Forms}

\section{A.1 Baseline}

\section{INTRODUCTION}

This activity is part of a research project funded by the regional Government of the Balearic Islands and conducted by a partnership between Florida State University, in the United States, Universidad Javeriana, in Colombia, and the University of the Balearic Islands.

This activity is composed of two main sections: (i) an experiment about environmental decision making, and (ii) a short survey.

\section{Once you read this paper sheet it will take you 5 minutes to participate.}

PAYMENT: During this activity you will have an opportunity to earn money. The amount of money you earn depends on the decisions that you and other participants in the experiment make. At the end of the activity you will be paid privately in cash for your decisions in the experiment.

\section{THIS EXPERIMENT}

In this experiment you will be randomly assigned to groups of 5. However, you will never know the identity of the other members of your group. The decisions of one group do not affect the decisions or earnings of other groups.

Each of the subjects in your group of 5 has been given 15 euros. Your decision task is to decide how much of your 15 euros you would like to voluntarily allocate to a local environmental organization, the Foundation for a Sustainable Development of the Balearics Islands (FSB). You will mark your decision on a decision form paper, including a participant number, which is your identification during the activity.

The FSB is a public-private non-profit organization, which was created on the 8th of July, 2004, whose aim is to propel a strategy of sustainable development. Their basic objectives are (1) heightening awareness of the residents and tourists to the environmental and heritage values of the Islands and the importance of their preservation; (2) inform residents and visitors alike, of the balance between human activity and the environment; and (3) fund raising in order to support different types of performances to be held in natural settings and initiatives which strive for sustainability.

Your earnings consist of the money you decide to keep up to 15 euros. At the end of the activity, we will give you your earnings in cash. The money you decide to allocate to the FSB will be placed in a sealed envelope with your participant number written down. At the end of the day, we will handle all the envelopes to the FSB. If you would like to track your allocation, you may do so by reaching Toni Maura, Projects Director FSB, at tonimaura@balears-sostenible.com or 971612425, and verify your allocation was made under your participant number. At the end of the study, the FSB will issue a certificate will all the allocations received.

\section{Example:}

Suppose that each member of your group voluntarily allocated 4 euros to the FSB so that the total allocation from all members is 4 euros $\times 5=20$ euros. Each group member's total earnings (the money that is kept) would then be 15 euros- 4 euros $=11$ euros. At the end of the session we would give you 11 euros in cash. We would then deposit the 4 euros you allocated to FSB in a 
sealed envelope with your participant number and at the end of the day we will handle all the envelopes to the FSB.

To summarize, you will earn: 15 euros minus the amount you decide to allocate to the FSB.

If you decide to participate, please raise your hand or call the attention of one of the researchers. In order to start the activity we need to have at least 10 participants. As soon as we reach that number, we will come by to give you the decision form and the survey. Once you decide to participate, please don't talk to anyone except one of the researchers.

CONFIDENTIALITY: All the information you will give us, is strictly confidential. You will never be asked to reveal your identity and your name will never be associated with any of your decisions. In order to keep your decisions private, please do not reveal your choices to any other participant.

\section{DECISION FORM}

\section{MY}

IDENTIFICATION

NUMBER IS:

How much would you like to:
Keep
euros
Allocate to FSB euros

\section{(These choices must sum to 15 euros)}

You can choose any amount of money to keep and any amount to allocate to the FSB, but the money you keep plus the money you allocate to the FSB must sum to 15 euros. 


\section{A.2 High Tax Treatment}

\section{INTRODUCTION}

This activity is part of a research project funded by the regional Government of the Balearic Islands and conducted by a partnership between Florida State University, in the United States, Universidad Javeriana, in Colombia, and the University of the Balearic Islands.

This activity is composed of two main sections: (i) an experiment about environmental decision making, and (ii) a short survey.

\section{Once you read this paper sheet it will take you 5 minutes to participate.}

PAYMENT: During this activity you will have an opportunity to earn money. The amount of money you earn depends on the decisions that you and other participants in the experiment make. At the end of the activity you will be paid privately in cash for your decisions in the experiment.

\section{THIS EXPERIMENT}

In this experiment you will be randomly assigned to groups of 5. However, you will never know the identity of the other members of your group. The decisions of one group do not affect the decisions or earnings of other groups.

Each of the subjects in your group of 5 has been given 15 euros. It is compulsory that each group member must allocate 10 euros from their initial 15 euros and give it to a local environmental organization, the Foundation for a Sustainable Development of the Balearics Islands (FSB). You must then decide how much of the remaining 5 euros you would like to voluntarily allocate to the FSB. You will mark your decision on a decision form paper, including a participant number, which is your identification during the activity.

The FSB is a public-private non-profit organization, which was created on the 8th of July, 2004, whose aim is to propel a strategy of sustainable development. Their basic objectives are (1) heightening awareness of the residents and tourists to the environmental and heritage values of the Islands and the importance of their preservation; (2) inform residents and visitors alike, of the balance between human activity and the environment; and (3) fund raising in order to support different types of performances to be held in natural settings and initiatives which strive for sustainability.

Your earnings consist of the money you decide to keep up to 5 euros. At the end of the activity, we will give you your earnings in cash. The 10 euros you must allocate plus the money you decide to voluntarily allocate to the FSB will be placed in a sealed envelope with your participant number written down. At the end of the day, we will handle all the envelopes to the FSB. If you would like to track your allocation, you may do so by reaching Toni Maura, Projects Director FSB, at tonimaura@balears-sostenible.com or 971612425, and verify your allocation was made under your participant number. At the end of the study, the FSB will issue a certificate will all the allocations received.

\section{Example:}

Suppose that each member of your group voluntarily allocated 4 euros to the FSB so that the total voluntary allocations from all members is 4 euros $\times 5=20$ euros in addition to the $5 \times 10$ euros $=50$ euros in compulsory allocations. Each group member's total earnings (the money that 
is kept) would then be 5 euros- 4 euros=1 euros. At the end of the session we would give you 1 euros in cash. We would then deposit the 14 euros $=10$ euros +4 euros you allocated (the compulsory + the voluntary) to FSB in a sealed envelope with your participant number and at the end of the day we will handle all the envelopes to the FSB.

To summarize, you will earn: 5 euros minus the amount you decide to allocate to FSB.

If you decide to participate, please raise your hand or call the attention of one of the researchers. In order to start the activity we need to have at least 10 participants. As soon as we reach that number, we will come by to give you the decision form and the survey. Once you decide to participate, please don't talk to anyone except one of the researchers.

CONFIDENTIALITY: All the information you will give us, is strictly confidential. You will never be asked to reveal your identity and your name will never be associated with any of your decisions. In order to keep your decisions private, please do not reveal your choices to any other participant.

\section{DECISION FORM}

\section{MY}

IDENTIFICATION

NUMBER IS:

How much would you like to:
Keep
euros
Allocate to FSB euros
(These choices must sum to 5 euros)

You can choose any amount of money to keep and any amount to allocate to the FSB, but the money you keep plus the money you allocate to the FSB must sum to 5 euros. 


\section{Appendix A.3 Low Tax Treatment}

\section{INTRODUCTION}

This activity is part of a research project funded by the regional Government of the Balearic Islands and conducted by a partnership between Florida State University, in the United States, Universidad Javeriana, in Colombia, and the University of the Balearic Islands.

This activity is composed of two main sections: (i) an experiment about environmental decision making, and (ii) a short survey.

\section{Once you read this paper sheet it will take you 5 minutes to participate.}

PAYMENT: During this activity you will have an opportunity to earn money. The amount of money you earn depends on the decisions that you and other participants in the experiment make. At the end of the activity you will be paid privately in cash for your decisions in the experiment.

\section{THIS EXPERIMENT}

In this experiment you will be randomly assigned to groups of 5. However, you will never know the identity of the other members of your group. The decisions of one group do not affect the decisions or earnings of other groups.

Each of the subjects in your group of 5 has been given 15 euros. It is compulsory that each group member must allocate 5 euros from their initial 15 euros and give it to a local environmental organization, the Foundation for a Sustainable Development of the Balearics Islands (FSB). You must then decide how much of the remaining 10 euros you would like to voluntarily allocate to the FSB. You will mark your decision on a decision form paper, including a participant number, which is your identification during the activity.

The FSB is a public-private non-profit organization, which was created on the 8th of July, 2004, whose aim is to propel a strategy of sustainable development. Their basic objectives are (1) heightening awareness of the residents and tourists to the environmental and heritage values of the Islands and the importance of their preservation; (2) inform residents and visitors alike, of the balance between human activity and the environment; and (3) fund raising in order to support different types of performances to be held in natural settings and initiatives which strive for sustainability.

Your earnings consist of the money you decide to keep up to 10 euros. At the end of the activity, we will give you your earnings in cash. The 5 euros you must allocate plus the money you decide to voluntarily allocate to the FSB will be placed in a sealed envelope with your participant number written down. At the end of the day, we will handle all the envelopes to the FSB. If you would like to track your allocation, you may do so by reaching Toni Maura, Projects Director FSB, at tonimaura@balears-sostenible.com or 971612425, and verify your allocation was made under your participant number. At the end of the study, the FSB will issue a certificate will all the allocations received.

\section{Example:}

Suppose that each member of your group voluntarily allocated 4 euros to the FSB so that the total voluntary allocations from all members is 4 euros $\times 5=20$ euros in addition to the $5 \times 5$ euros $=25$ euros in compulsory allocations. Each group member's total earnings (the money that 
is kept) would then be 10 euros- 4 euros $=6$ euros. At the end of the session we would give you 6 euros in cash. We would then deposit the 9 euros $=5$ euros +4 euros you allocated (the compulsory + the voluntary) to FSB in a sealed envelope with your participant number and at the end of the day we will handle all the envelopes to the FSB.

To summarize, you will earn: 10 euros minus the amount you decide to allocate to FSB.

If you decide to participate, please raise your hand or call the attention of one of the researchers. In order to start the activity we need to have at least 10 participants. As soon as we reach that number, we will come by to give you the decision form and the survey. Once you decide to participate, please don't talk to anyone except one of the researchers.

CONFIDENTIALITY: All the information you will give us, is strictly confidential. You will never be asked to reveal your identity and your name will never be associated with any of your decisions. In order to keep your decisions private, please do not reveal your choices to any other participant.

\section{DECISION FORM}

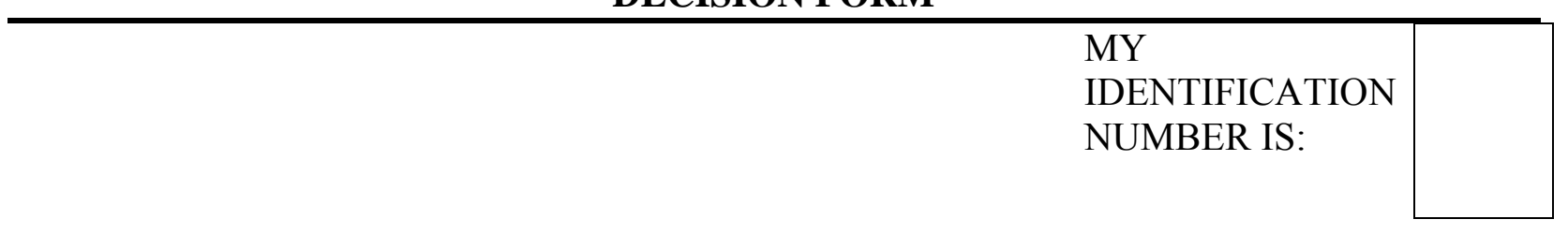

How much would you like to:
Keep euros
Allocate to FSB euros (These choices must sum to 10 euros)

You can choose any amount of money to keep and any amount to allocate to the FSB, but the money you keep plus the money you allocate to the FSB must sum to 10 euros. 


\section{Appendix A.4 Matching Treatment}

\section{INTRODUCTION}

This activity is part of a research project funded by the regional Government of the Balearic Islands and conducted by a partnership between Florida State University, in the United States, Universidad Javeriana, in Colombia, and the University of the Balearic Islands.

This activity is composed of two main sections: (i) an experiment about environmental decision making, and (ii) a short survey.

\section{Once you read this paper sheet it will take you 5 minutes to participate.}

PAYMENT: During this activity you will have an opportunity to earn money. The amount of money you earn depends on the decisions that you and other participants in the experiment make. At the end of the activity you will be paid privately in cash for your decisions in the experiment.

\section{THIS EXPERIMENT}

In this experiment you will be randomly assigned to groups of 5. However, you will never know the identity of the other members of your group. The decisions of one group do not affect the decisions or earnings of other groups.

Each of the subjects in your group of 5 has been given 15 euros. Your decision task is to decide how much of your 15 euros you would like to voluntarily allocate to a local environmental organization, The Foundation for a Sustainable Development of the Balearics Islands (FSB). Additionally, for each euro you voluntarily allocate to FSB, we will match your contribution by allocating an additional euro to the FSB. You will mark your decision on a decision form paper, including a participant number, which is your identification during the activity.

The FSB is a public-private non-profit organization, which was created on the 8th of July, 2004, whose aim is to propel a strategy of sustainable development. Their basic objectives are (1) heightening awareness of the residents and tourists to the environmental and heritage values of the Islands and the importance of their preservation; (2) inform residents and visitors alike, of the balance between human activity and the environment; and (3) fund raising in order to support different types of performances to be held in natural settings and initiatives which strive for sustainability.

Your earnings consist of the money you decide to keep up to 15 euros. At the end of the activity, we will give you your earnings in cash. The money you decide to allocate to the FSB will be placed together with the money we will match in a sealed envelope with your participant number written down. At the end of the day, we will handle all the envelopes to the FSB. If you would like to track your allocation, you may do so by reaching Toni Maura, Projects Director FSB, at tonimaura@balears-sostenible.com or 971612425, and verify your allocation was made under your participant number. At the end of the study, the FSB will issue a certificate will all the allocations received.

\section{Example:}

Suppose that each member of your group allocated 4 euros to the FSB so that the total allocation from all members is 4 euros $\times 5=20$ euros. Each group member's total earnings (the money that is 
kept) would then be 15 euros- 4 euros=11 euros. At the end of the session we would give you 11 euros in cash. We would then deposit the 4 euros you allocated to FSB plus the 4 euros we will match in a sealed envelope with your participant number and at the end of the day we will handle all the envelopes to FSB.

To summarize, you will earn: 15 euros minus the amount you decide to allocate to FSB.

If you decide to participate, please raise your hand or call the attention of one of the researchers. In order to start the activity we need to have at least $\mathbf{1 0}$ participants. As soon as we reach that number, we will come by to give you the decision form and the survey. Once you decide to participate, please don't talk to anyone except one of the researchers.

CONFIDENTIALITY: All the information you will give us, is strictly confidential. You will never be asked to reveal your identity and your name will never be associated with any of your decisions. In order to keep your decisions private, please do not reveal your choices to any other participant.

\section{DECISION FORM}

\begin{tabular}{l|l} 
MY \\
IDENTIFICATION \\
NUMBER IS:
\end{tabular}

How much would you like to:
Keep
euros
Allocate to FSB euros (These choices must sum to 15 euros)

You can choose any amount of money to keep and any amount to allocate to the FSB, but the money you keep plus the money you allocate to the FSB must sum to 15 euros.

For each euro you voluntarily allocate to FSB, we will match your contribution by allocating an additional euro to the FSB 
Appendix B. Questionnaire 


\section{SURVEY}

\begin{tabular}{|c|c|}
\hline \multicolumn{2}{|r|}{ MY IDENTIFICATION NUMBER IS: } \\
\hline 1 & NATIONALITY \\
\hline 2 & AGE \\
\hline 01 & $\square 30$ years old or below \\
\hline 02 & $\square$ Between 31 and 45 \\
\hline 03 & $\square$ Between 46 and 60 \\
\hline 04 & 61 or older \\
\hline 3 & EDUCATION \\
\hline 01 & $\square \quad$ No formal education \\
\hline 02 & $\square$ Pre-school or kindergarten \\
\hline 03 & 口 Primary school \\
\hline 04 & ․ Secondary school \\
\hline 05 & $\square$ Bachelor degree \\
\hline 06 & $\square$ Master's degree or $\mathrm{PhD}$ \\
\hline 4 & WORKING STATUS \\
\hline 01 & $\checkmark$ Unemployed (looking for a job) \\
\hline 02 & $\square$ Student \\
\hline 03 & $\begin{array}{l}\text { Retired and / or other income } \\
\text { sources }\end{array}$ \\
\hline 04 & 口 Homemaker \\
\hline 05 & $\square$ Working \\
\hline 06 & $\square$ Volunteer \\
\hline 07 & 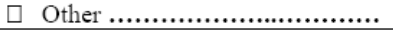 \\
\hline 5 & PROFESSIONAL OCCUPATION \\
\hline 01 & 口 Senior official and/or manager \\
\hline 02 & $\square$ Professional \\
\hline 03 & $\begin{array}{l}\text { Technician and/or associated } \\
\text { professional }\end{array}$ \\
\hline 04 & $\square$ Administrative support \\
\hline 05 & $\begin{array}{l}\text { Restaurant, personnel and/or } \\
\text { commercial service worker }\end{array}$ \\
\hline 06 & $\begin{array}{l}\text { Skilled agricultural and/or } \\
\text { fishery worker }\end{array}$ \\
\hline 07 & $\square$ Artisan \\
\hline 08 & $\begin{array}{l}\text { Manufacturing, construction } \\
\text { and/or mining worker }\end{array}$ \\
\hline 09 & $\square$ Military service \\
\hline & $\square \quad$ Other ............. \\
\hline 6 & $\begin{array}{l}\text { WITH WHOM DID YOU COME } \\
\text { TO MAJORCA WITH? }\end{array}$ \\
\hline 01 & Came alone \\
\hline 02 & With only your partner \\
\hline 03 & $\begin{array}{l}\text { With your family (without } \\
\text { children) }\end{array}$ \\
\hline 04 & $\begin{array}{l}\text { With your family (including } \\
\text { children) }\end{array}$ \\
\hline 05 & With both family and friends \\
\hline 06 & With only friends \\
\hline 07 & $\begin{array}{l}\text { With co-workers and/or school } \\
\text { friends }\end{array}$ \\
\hline
\end{tabular}

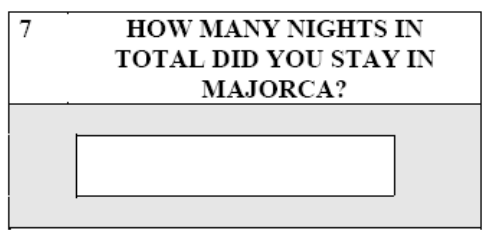

8 WHY DID YOU COME TO THE ISLAND? (please select no more than 4 answers)

$01 \square$ Affordability of price

$02 \square$ Participating in the night life

$03 \square$ Enjoying comfort and spoiling myself

$04 \square$ Enjoying time with people with whom I came

$05 \square$ Enjoying the landscape and nature

$06 \square$ Doing something for my looks and well-being

$07 \square$ Sport activities

$08 \square$ Enjoying the sun and water

$09 \square$ Enjoying the nice weather

$10 \square$ Availability of transport and proximity to my home country

$11 \square$ Availability of activities for children

$12 \square$ Quality of hotels/ apartments

$13 \square$ Excursions/walks

$14 \square$ Other.

9 PLEASE INDICATE THE NUMBER OF TIMES (INCLUDING THIS TRIP) THAT YOU HAVE VISITED THE BALEARIC ISLANDS

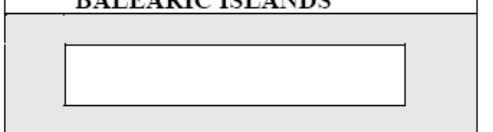

10 PLEASE INDICATE YOUR OVERALL LEVEL OF SATISFACTION IN EACH OF THE FOLLOWING FACTORS

\begin{tabular}{|c|c|c|c|c|c|c|}
\hline & & $\begin{array}{l}\overrightarrow{8} \\
8 \\
80 \\
2 \\
\end{array}$ & Ð & 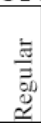 & $\underset{\widetilde{F}}{\vec{\sim}}$ & 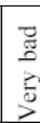 \\
\hline 01 & Scenery & $\square$ & $\square$ & $\square$ & $\square$ & $\square$ \\
\hline 02 & Beach & $\square$ & $\bar{\square}$ & $\square$ & $\square$ & $\square$ \\
\hline 03 & $\begin{array}{l}\text { Environmental } \\
\text { quality }\end{array}$ & $\square$ & $\square$ & $\square$ & $\mathrm{\square}$ & $\square$ \\
\hline 04 & $\begin{array}{l}\text { Cleanliness of } \\
\text { public areas }\end{array}$ & $\square$ & $\square$ & $\square$ & $\square$ & $\square$ \\
\hline 05 & $\begin{array}{l}\text { Prices of food } \\
\text { and beverage }\end{array}$ & $\square$ & $\square$ & $\square$ & $\square$ & $\square$ \\
\hline 06 & $\begin{array}{l}\text { Prices of leisure } \\
\text { activities }\end{array}$ & $\square$ & $\square$ & $\square$ & $\square$ & - \\
\hline 07 & $\begin{array}{l}\text { Treatment as a } \\
\text { customer }\end{array}$ & $\square$ & $\square$ & $\square$ & $\square$ & - \\
\hline 08 & $\begin{array}{l}\text { Hospitality } \\
\text { from local } \\
\text { people }\end{array}$ & $\square$ & $\square$ & $\square$ & $\mathrm{Q}$ & $\square$ \\
\hline 09 & $\begin{array}{l}\text { Safety and } \\
\text { Security }\end{array}$ & $\square$ & $\square$ & $\square$ & $\square$ & $\square$ \\
\hline 10 & $\begin{array}{l}\text { Tourist } \\
\text { information }\end{array}$ & $\square$ & $\square$ & $\square$ & $\square$ & | ப \\
\hline
\end{tabular}

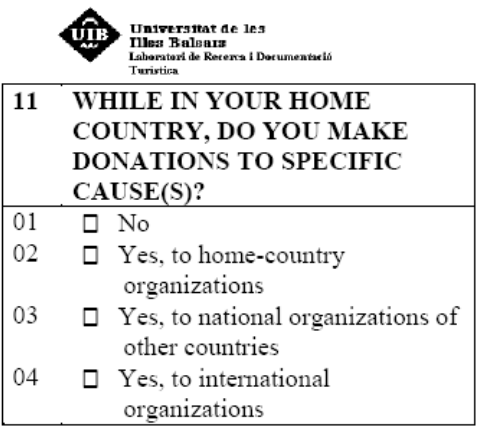

\begin{tabular}{|ll|}
\hline 12 & $\begin{array}{l}\text { PLEASE SPECIFY THE } \\
\text { CAUSE(S) YOU SUPPORT }\end{array}$ \\
\hline 01 & $\square$ Religious \\
02 & $\square$ Environmental protection \\
03 & $\square$ Health organizations \\
04 & $\square$ Education organizations \\
05 & $\square$ Poverty alleviation \\
06 & $\square$ Others: \\
& $\ldots \ldots \ldots \ldots \ldots \ldots \ldots \ldots \ldots \ldots \ldots \ldots \ldots \ldots \ldots \ldots \ldots \ldots \ldots \ldots \ldots \ldots \ldots \ldots \ldots$ \\
\hline
\end{tabular}

\begin{tabular}{|c|c|c|c|}
\hline \multirow[t]{2}{*}{13} & \multicolumn{3}{|l|}{$\begin{array}{l}\text { WHILE IN YOUR HOME } \\
\text { COUNTRY, DO YOU... }\end{array}$} \\
\hline & & $\frac{1}{2}$ & z \\
\hline 01 & Recycle? & $\square$ & $\square$ \\
\hline 02 & $\begin{array}{l}\text { Have a close contact to } \\
\text { nature (e.g. hiking, biking, } \\
\text { etc.)? }\end{array}$ & $\square$ & $\square$ \\
\hline 03 & $\begin{array}{l}\text { Visit protected natural } \\
\text { areas? }\end{array}$ & $\square$ & $\square$ \\
\hline
\end{tabular}

\begin{tabular}{|ll|ll|}
\hline 14 & \multicolumn{3}{l|}{$\begin{array}{l}\text { DO YOU KNOW WHAT THE } \\
\text { BALEARIC ISLANDS' GREEN } \\
\text { CARD IS? }\end{array}$} \\
\hline 01 & $\square$ Yes & 02 & $\square$ No \\
\hline
\end{tabular}

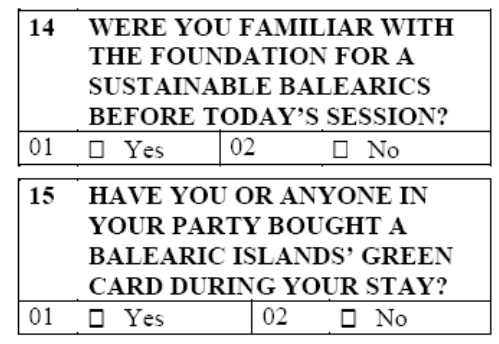

THANKS FOR YOUR COOPERATION 